\title{
PENGARUH SUPLEMENTASI MINYAK IKAN TERPROTEKSI TERHADAP KECERNAAN NUTRIEN BAHAN KERING (BK ) DAN BAHAN ORGANIK (BO) PADA KAMBING PERANAKAN ETTAWA (PE)
}

\author{
Tri Ida Wahyu Kustyorini \\ Fakultas Peternakan, Universitas Kanjuruhan Malang, \\ J1. S. Supriadi No.48 Malang \\ Email: triida@unikama.ac.id
}

Penelitian ini bertujuan untuk mengetahui tingkat kecernaa bahan kering (BK) dan bahan organik (BO) pada kambing peranakan ettawa. Materi yang digunakan adalah 9 ekor kambing jantan peranakan ettawa dan minyak ikan. Metode penelitian yang digunakan adalah metode percobaan lapang dengan menggunakan Rancangan Acak Kelompok (RAK). Perlakuan yang diujikan adalah P0: pakan control (rumput gajah dan konsentrat), P1 (rumput gajah, konsentrat + minyak ikan), P2 (rumput gajah, konsentrat + Ca-minyak ikan). Setiap perlakuan kambing PE diulang sebanyak 3 kali. Variabel yang diamati pada penelitian adalah kecernaan bahan kering (BK) dan bahan organik (BO).hasil penelitian dianalisis dengan mnggunakan analisis anova dan jika terdapat pengaruh dilanjut dengan uji BNT. Berdasarkan hasil penelitian menunjukkan bahwa adanya perbedaan yang tidak nyata $\mathrm{P}>0,05$ terhadap kecernaan bahan kering (BK) dan kecernaan bahan organik (BO) pada kambing peranakan ettawa. Kecernaan BK tertinggi pada P0 sebesar $92,70 \%$ dan kecernaan BO tertinggi juga pada P0 sebesar 86,21\%. Kesimpulan yang diperoleh dari hasil penelitian ini yaitu pemberian minyak ikan terproteksi tidak memberikan pengaruh yang nyata terhadap tingkat kecernaan BK dan BO.

Kata kunci: suplememntasi; proteksi; minyak ikan; peranakan ettawa; kecernaan

\section{ABSTRACT}

This study aims to determine the level of dry matter digestibility and organic matter in ettawa breed goats. The material used was 9 male ettawa breeds and fish oil. The research method used is a field trial method using Randomized Block Design (RBD). The treatments tested were P0: control feed (elephant grass and concentrate), P1 (elephant grass, concentrate + fish oil), P2 (elephant grass, concentrate + fish oil Ca-oil). Each treatment of PE goats is repeated 3 times. The variables observed in the study were dry matter digestibility and organic matter. The results of the study were analyzed by using ANOVA analysis. Based on the results of the study showed that there was no significant difference $\mathrm{P}>0.05$ to the dry matter digestibility (DM) and digestibility of organic matter (OM) in ettawa breeds. The highest DM digestibility at P0 was $92.70 \%$ and the highest $\mathrm{OM}$ digestibility was also at $\mathrm{P} 0$ of $86.21 \%$. The conclusion obtained from the results of this study is that the provision of protected fish oil does not have a significant effect on the digestibility level of DM and OM.

Keywords: suplementation, protected, fish oil, dry matter digestibility, organic matter digestibility, ettawa goats.

\section{Pendahuluan}

Hewan ruminansia berukuran kecil seperti kambing dalam usaha peternakan memiliki potensi yang besar. Menurut Sarwono (2008), kambing Peranakan Ettawa (PE) merupakan kambing hasil persilangan antara bangsa kambing Ettawa yang berasal dari India dengan kambing kacang (kambing asli Indonesia). Pada dasarnya kambing PE termasuk dalam ternak dwiguna. 
Pakan merupakan salah satu faktor penting dalam usaha peternakan. Pakan berperan utama dalam pemenuhan hidup pokok, pertumbuhan, reproduksi dan produksi susu. Pakan ternak ruminansia umumnya memanfaatkan bahan pakan dengan kandungan serat yang tinggi serta by product pertanian yang memiliki kualitas relative rendah, sehingga ternak seringkali mengalami defisien nutrient. Dengan demikian untuk menutupi kekurangan tersebut salah satu alternatife yaitu penggunaan minyak ikan. Minyak ikan sebagai sumber gizi baik bagi kehidupan manusia maupun ternak, sangat banyak manfaatnya karena merupakan salah satu sumber minyak dan protein.

Lemak sebagai senyawa non polar, tidak mudah larut dalam medium cairan rumen, karena itu lemak cenderung berasosiasi dengan partikel pakan dan mikroba rumen, bentuk asosiasinya berupa penutupan permukaan secara fisik oleh lemak (Pantoja et al., 1994), sehingga kadar lemak yang tinggi pada ransum mengganggu pertumbuhan mikroba rumen. Penambahan lemak dalam ransum dapat menurunkan kecernaan serat kasar karena asam lemak rantai panjang menghambat aktivitas mikroba rumen (Palmquist, dkk, 1986).

Kecernaan serat dapat diperbaiki melalui aksi penghilangan pengaruh negatif asam lemak terhadap bakteri. Aktivitas antibakteri dari asam lemak rantai panjang dapat berkurang oleh proteksi asam lemak. Oleh karena itu suplementasi minyak terproteksi bertujuan supaya minyak tidak menganggu fermentasi di dalam rumen dan menyediakan asam lemak bagi induk semangnya. Bagian pakan yang dicerna ternak merupakan selisih antara jumlah pakan yang terkonsumsi dengan yang keluar lewat feses. Rendahnya kecernaan rumput alam dan jerami tanaman pangan menghasilkan TDN kurang dari 50\% sehingga jumlah pakan yang diberikan harus digandakan dari kebutuhan. Namun, cara ini sulit diterapkan karena daya konsumsi ternak terbatas. Oleh karena itu perlu dilakukan penelitian tentang pemanfaatan minyak ikan terproteksi terhadap kecernaan BK dan BO pada kambing PE.

\section{Materi dan Metode}

Materi yang digunakan dalam penelitian ini adalah kambing peranakan Ettawa jantan 9 ekor sebagai ternak percobaan dengan umur \pm 2 th dan $\mathrm{BB} \pm 25 \mathrm{~kg}$; pakan hijauan berupa rumput gajah (Pennisetum purpureum) sebagai pakan basal dan konsentrat jadi, dengan kandungan nutrien yang dapat dilihat pada tabel 1. Konsentrat kemudian ditambahkan berbagai sumber minyak sebagai perlakuan; minyak Ikan (Fish oil). 
Metode penelitian yang digunakan adalah Rancangan Acak Kelompok (RAK) dengan 3 perlakuan dan 3 kelompok berdasarkan bobot badan (BB). Penempatan ternak dalam penelitian berdasarkan kisaran bobot badan dan penempatan pakan perlakuan dilakukan secara acak/random. Adapun pakan perlakuan sebagai berikut:

P0 : Rumput gajah + konsentrat (1:1) (pakan control)

P1 : Pakan kontrol + minyak ikan 4\%

P2 : Pakan kontrol + Ca-minyak ikan 4\%

Komposisi kimia ransum yang digunakan tercantum dalam tabel 1.

Tabel 1. Komposisi Kimia Rumput Gajah dan Konsentrat.

\begin{tabular}{lllllll}
\hline No & Bahan Pakan & $\begin{array}{l}\text { BK } \\
(\%)\end{array}$ & $\begin{array}{l}\text { PK } \\
(\% \mathrm{BK})\end{array}$ & $\begin{array}{l}\text { LK } \\
(\% \mathrm{BK})\end{array}$ & $\begin{array}{l}\text { SK } \\
(\% \mathrm{BK})\end{array}$ & $\begin{array}{l}\text { ABU } \\
(\% \mathrm{BK})\end{array}$ \\
\hline 1 & Rumput Gajah & 19,30 & 8,45 & 1,35 & 39,48 & 12,17 \\
2 & Konsentrat & 80,20 & 15,13 & 6,98 & 16,10 & 9,80 \\
\hline
\end{tabular}

Frekuensi pemberian pakan sebanyak dua kali sehari yaitu pagi hari pukul 07.00 WIB dan sore hari pukul 15.00 WIB. Penelitian ini dilakukan secara in vivo. Pada fase percobaan in vivo meliputi 3 periode yaitu periode persiapan, pendahuluan dan periode koleksi data.

Variabel yang diamati dalam penelitian ini adalah:

a. Kecernaan bahan kering

b. Kecernaan bahan organik

Data yang diperoleh dianalisis menggunakan Rancangan Acak Kelompok (RAK) - Apabila perlakuan memberikan pengaruh maka dilanjutkan dengan uji Beda Nyata Terkecil.

\section{Hasil dan Pembahasan}

\section{Kecernaan Bahan Kering (BK)}

Dari hasil analisis ragam menunjukkan bahwa tingkat penggunaan hijauan rumput gajah, konsentrat dan minyak ikan terproteksi menunjukkan adanya pengaruh yang tidak nyata $(\mathrm{P}>0,05)$ terhadap kecernaan bahan kering $(\mathrm{BK})$ pada kambing $(\mathrm{PE})$. Rataan kecernaan bahan kering disajikan pada tabel 2

Upaya untuk menghasilkan performan produksi yang tinggi, ternak memerlukan nutrisi. Nutrien ini untuk hidup pokok (maintenance) dan berbagai produksi (production. Faktor yang harus diperhatikan adalah jumlah makanan yang diberikan, semakin banyak jumlah makanan yang dikonsumsi setiap hari, akan semakin memberikan kesempatan untuk menghasilkan produksi tinggi. Peningkatan produksi yang diperoleh dari konsumsi 


\section{Jurnal Sains Peternakan}

Vol 6 No 2, Desember 2018, 57-62

ISSN 2579-4450

makanan yang lebih tinggi biasanya berkaitan dengan peningkatan efisiensi proses-proses produksi, sehingga proporsi untuk kebutuhan pokok menurun sedangakan produksi meningkat.

Kecernaan dari suatu bahan pakan adalah bahan pakan yang tidak diekskresikan dalam feses dan dianggap diabsorbsi oleh ternak (Mc Donald et al, 1988). Kecernaan ada dua macam, yaitu kecernaan sesungguhnya (true digestibility) dan kecernaan semu (apparent digestibility). Kecernaan sesungguhnya memperhitungkan material bukan bahan pakan yang ada di dalam feses seperti mukosa usus, enzim, dan bakteri. Sedangkan kecernaan semu menganggap semua nutrien yang ada dalam feses berasal dari bahan pakan yang tidak tercerna (Cullison, 1982).

Tabel 2. Rata-rata kecernaan bahan organik pada masing-masing perlakuan kambing (PE) selama penelitian.

\begin{tabular}{lr}
\hline Perlakuan & Rata-rata $(\%)$ \\
\hline P0 & 92.70 \\
P1 & 91.28 \\
P2 & 91.57 \\
\hline
\end{tabular}

Berdasarkan analisis ragam menunjukkan bahwa suplementasi minyak ikan terproteksi tidak memberikan pengaruh $(\mathrm{P}>0,05)$ terhadap kecernaan bahan kering $(\mathrm{BK})$. Kecernaan tertinggi pada perlakuan P0 yaitu sebesar 92,70\% dan terendah pada perlakuan P1 sebesar 91,28\%. Hal ini dikarenakan pada perlakuan P1 terdapat suplementasi minyak ikan tanpa proteksi, sehingga keberadaan minyak ikan dapat menyebabkan terselubunginya partikel pakan oleh minyak. Pakan yang diselubungi minyak dapat menghambat interaksi antara pakan dengan mikroorganisme rumen, sehingga mikroorganisme rumen sulit untuk mendegradasi.

\section{Kecernaan Bahan Organik (BO)}

Dari hasil analisis ragam menunjukkan bahwa tingkat penggunaan hijauan rumput gajah, konsentrat dan minyak ikan menunjukkan adanya pengaruh yang tidak nyata $(\mathrm{P}>0,05)$ terhadap kecernaan bahan organik $(\mathrm{BO})$ pada kambing $(\mathrm{PE})$. Rataan kecernaan bahan organic selama penelitian disajikan pada Tabel 3.

Perlakuan penelitian memberikan pengaruh yang tidak nyata dikarenakan kecernaan bahan organik (BK) juga tidak terpengaruh oleh suplementasi minyak ikan terproteksi, sehingga kecernaan bahan organik juga tidak terpengaruh. Bahan kering dapat diuraikan menjadi bahan organik dan anorganik. Bahan organik terdiri dari protein, 


\section{Jurnal Sains Peternakan}

Vol 6 No 2, Desember 2018, 57-62

ISSN 2579-4450

lemak, karbohidrat yang terdiri dari bahan ekstrak tanpa $\mathrm{N}$ dan serat kasar. Sedangkan mineral-mineral merupakan penyusun dari bahan anorganik (Hartutik dan Surisdiarto, 1993).

Tabel 3. Rata-rata kecernaan bahan organik pada masing-masing perlakuan kambing (PE) selama penelitian

\begin{tabular}{lr}
\hline Perlakuan & Rata-rata $(\%)$ \\
\hline P0 & 86.21 \\
P1 & 85.67 \\
P2 & 85.34 \\
\hline
\end{tabular}

Tillman et al ., (1998) menambahkan bahwa kecernaan bahan kering dengan sendirinya akan mempengaruhi kecernaan bahan organik, walaupun kecernaan bahan kering juga dipengaruhi oleh kecernaan mineral. Kecernaan mineral tidak berpengaruh besar terhadap kecernaan suatu bahan pakan sebab kadar mineral dari feses yang berasal dari tubuh besar, sehingga kecernaan mineral pengaruhnya kecil.

\section{Kesimpulan}

berdasarkan hasil penelitian dapat disimpulkan bahwa suplementasi minyak ikan terproteksi tidak memberikan perngaruh yang nyata terhadap kecernaan bahan kering (BK), bahan organik (BO) pada kambing peranakan Ettawa (PE).

\section{Ucapan Terimakasih}

Ucapan terima kasih disampaikan kepada semua pihak terutama Laboratorium Lapang Fakultas Peternakan Universitas Kanjuruhan Malang yang telah banyak membantu sejak persiapan hingga terselenggaranya penelitian ini dengan baik.

\section{Daftar Pustaka}

Engle, T.E., J.W. Spears, T.A. Asmstrong, C.I. Wright, and J. Odle. 2000. Effect of dietary copper source and concentration on carcass characteristic and lipid and cholesterol metabolism in growing and finishing steers. J. Anim. Sci. 78:1053-1059.

Hatmaya, R.T. 2008. Efek Berbagai Pakan Komplit Terhadap Daya Cerna Lemak dan Serat Kasar Pada Sapi Perah [Skripsi]. Fakultas Kedokteran Hewan. Universitas Airlangga. 6-12. 
Pantoja, J., J.L. Firkins, M.L. Estridge and B.L. Hull. 1994. Effect of fat saturation and source of fiber an site of nutrient digestion and milk production by lactating dairy cows. J. dairy Sci. 77:2342-2356.

Palmquist, D.L., Jenkins, T.C. and Joyner, A.E. 1986. Effect of dietatry fat and calcium source on insoluble soap formation in the rumen. J. Dairy Sci. 69:1020-1025

Tillman, A.D. H. Hartadi, S. Reksohadiprodjo, S. Prawirokusumo dan S. Lebdosoekojo. 1991. Ilmu Makanan Ternak Dasar. Gajah Mada University Press. Fakultas Peternakan, UGM, Yogyakarta. 